\title{
DO THE ORTHODOX RULES OF LAWYERING PERMIT THE PUBLIC INTEREST ADVOCATE TO "DO THE RIGHT THING?": A CASE STUDY OF HIV-INFECTED PRISONERS
}

\section{JUDITH MOSOFF*}

The author explores the area of public interest litigation using her experiences as counsel for an HIV infected prisoner to illustrate public interest concepts and concerns. The author first provides a background to the case and then discusses the special considerations that must be addressed in public interest litigation. She points out how this approach differs from private interest litigation in such areas as the overall goal of litigation and in the relationship between counsel and other actors. In concluding. the author notes particular areas that need to be examined and improved for more effective public interest litigation.
En évoquant son expérience d'avocate représentant un prisonnier séropositif. I' auteure explore le secteur des liriges d'imérêt public pour illustrer quelles sont les notions et préoccupations propres à ce domaine. Elle fournit d'abovd r histoire générale du cas pour aborder ensuite les problèmes particuliers à traiter dans les litiges de ce type. Elle souligne en quoi cette approche differe de celle qu'on adopte dans les litiges du secteur privé et examine quel est l'objectif général des litiges, ainsi que le rapport qui existe entre l'arocar(e) et les autres parties. En conclusion. lautcure note les secteurs qu'il est nécessaire d'examiner et d'améliorer pour que les litiges d'intérêt public soient plus efficacement abordés.

\section{TABLE OF CONTENTS}

I. INTRODUCTION .................... 1258

II. BACKGROUND TO THE HIV-INFECTED

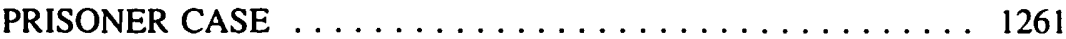

III. THE ROLE OF COUNSEL IN PUBLIC INTEREST

LITIGATION: SPECIAL CONSIDERATIONS . . . . . . . . . 1263

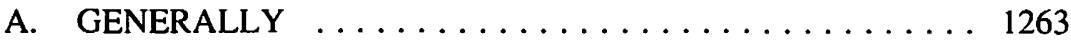

B. FUNDING ARRANGEMENTS FOR

THE LITIGATION . . . . . . . . . . . . . . . . . . . . . . 1264

C. DIFFERENT PARTIES IN THE LITIGATION

AND DIFFERENT INTERESTS . . . . . . . . . . . . . . . 1264

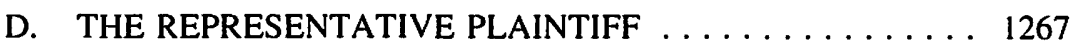

E. SHORT-TERM AND LONG-TERM

CONSEQUENCES OF LITIGATION . . . . . . . . . 1270

IV. CONCLUSIONS $\ldots \ldots \ldots \ldots \ldots \ldots \ldots \ldots \ldots \ldots \ldots \ldots$

\section{INTRODUCTION}

Suppose that you are a relatively experienced trial lawyer who has spent the last ten years of practice doing personal injury work. Because you are known to be interested in disability issues, a spokesperson for prisoners' rights in your community asks you to represent an HIV-infected prisoner who has been treated in a discriminatory way. The prisoners' group, as an organization, is interested in the case because of its effect on

Assistant Professor, Faculty of Law, University of British Columbia. The author gratefully acknowledges the assistance of Phil Bryden and Claire Culhane for their helpful suggestions on earlier drafts of this paper. Special thanks to Jim Russell, Isabel Grant and Lesley Stalker. 
prison conditions generally and it wants to remain involved in the case. For you as counsel, is there anything special about this legal problem since it is a matter of concern to a large number of people and addresses a pressing social problem?

For many years, legal scholars, social scientists and legal practitioners have worked on a variety of issues that are loosely conceived as public interest matters.' While the judiciary has struggled with how the different aspects of public interest matters should be best brought before the courts, ${ }^{2}$ the underlying assumption is that the rest of the lawyering process is the same as representing private clients.

This paper will explore the social and ethical issues that pervade public interest advocacy and will argue, from the lawyer's perspective, that the different interests involved in private and public interest litigation result in a difference in process that impinges on all of the participants in the process. For the purposes of the paper, the "lawyer's perspective" refers less to the perspective as defined by what the law society rules say about what lawyers need to take into account in practice, and more to what the experienced public interest lawyer must learn and take into account in order to do a

There is no general consensus about what we mean by public interest law and debate continues on whether there is a significant difference between private and public litigation. In the classic article by Professor A. Chayes, "The Role of the Judge in Public Law Litigation" (1976) 89 Harvard L. Rev. at 1281, the focus was on the decree as a central feature of public law litigation which could result in judicial supervision over a matter. such as prison conditions. P. Bryden. "Public Interest Intervention in the Courts" (1987) 66 Can. Bar Rev. at 490, describes public interest advocacy as a fundamental tenet of democracy. When people see that a public body wields authority over them, especially if a group of people perceive themselves as like-minded, they will attempt to influence the perceived authority over them, either directly with politicians or through the courts.

In Canada, the most restrictive approach to the law of standing permits only Attomeys-General to raise matters on behalf of the public interest, but over time the Supreme Court of Canada has expanded the law to allow standing to persons who have not had the traditional unique interest in the outcome of litigation. Sec Minister of Justice v. Borowski, [1981] 2 S.C.R. 575, Nova Scotia Censors v. MacNeil, [1976] 2 S.C.R. 215, Thorson v. A-G Canada, [1975] I S.C.R. However, as the courts are required to determine significant Charter issues, the law of standing may be defined somewhat differently and more creative approaches may be required to permit the views of the public interest to be brought before the court. For a discussion of techniques that may bring these matters before the courts, including such matters as broadened standing rules, social scientific data as evidence, see R. Sharpe, eds., Charter Litigation (Toronto: Butterworths, 1987). J. Welch "No Room at the Top: Interest Group Intervenors and Charter Litigation in the Supreme Court of Canada" (1985) 43 U.T. Fac. L. Rev. 204-31. The early indications, however, are that the Supreme Court of Canada is not inclined to broaden the rules of standing to permit Charter litigation for public interest groups.

In The Canadian Council of Churches v. The Queen and the Minister of Employmem and Immigration, Unreported. No. 21946, January 23, 1992, S.C.C., the court refused to grant standing to a public interest group to challenge the constitutionality of refugec legislation although the group had demonstrated a genuine and longstanding connection to the issues. Mr. Justice Cory, speaking for the Court reiterated the principle that standing should be granted to public interest groups only to prevent the immunization of legislation from review and that the existing principles need not and should not be expanded. Consideration should be given to three factors: the seriousness of the issue, whether the plaintiff is directly or genuinely interested in the impugned legislation and whether there is another reasonable and effective way to bring the issue before the court. In this case the Council was not granted standing because it could be shown, on a balance of probabilities, that the legislation would be subject to attack by a private litigant. 
proper job. ${ }^{3}$ To illustrate the general problem, the paper will describe the particular issues that arose in acting as counsel in a case concerning the treatment of prisoners who are HIV positive. ${ }^{4}$

The differences between the traditional practice of law and public interest law are grounded in different views of what the law is, why it is important and how it works. In the traditional view, the legal system is machinery that generates decisions and the law provides a system of rules through which a decision or a result can be estimated. The lawyer assists a particular individual in a particular dispute at a particular moment by recreating facts and articulating the individual's interests with respect to the dispute.

A public interest approach involves a different analysis and perception. This view exists through a perspective of group interest rather than individual interest. This approach sees the legal system as part of a process, one institution among several through which society orders its affairs. The court system is but one element of decision-making in the process of ordering and re-ordering. Any particular issue or problem is one facet of a range of issues and outcomes that speak to the group interest being pursued. The role of the public interest lawyer is to assist a group in articulating itself in matters of law, but with a wider view of the meaning of law than the resolution of a particular dispute, because to understand and work within a group perspective, demands a more sophisticated analysis of the interaction between matters of law, civil society and the state.

Litigation is always only one option among many that may be pursued. The decision to litigate a public interest matter will not be made precipitously and represents only one aspect of a multi-faceted approach. However, the problems that arise in public interest litigation provide good examples of the ways in which the traditional practice of law and the public interest approach differ. The system of litigation has evolved for the purposes of resolving private disputes and is not always a good fit for advancing a group perspective.

In this paper, I will first set out the background of the "HIV and Prisons" case. Secondly, I will outline the special considerations in public interest matters generally, funding arrangements for the litigation, the particular issues that arise because of the different parties, inclusion of a representative plaintiff, and the recognition of short-term and long-term consequences of litigation. Finally, I will describe the conclusions for a new form of practice in public interest litigation.

3. Although public interest lawyers may believe that the traditional rules of lawyering are less helpful to their dilemmas, there is no suggestion here that the current rules are less binding on lawyers doing certain kinds of legal work. Ultimately however, the rules of the professional bodies, that is the Law Societies, may need to be modified to encompass the issues involved in public interest advocacy.

4. As AIDS is a relatively new disease for medicine and an even newer legal problem, there is little guidance from the usual resource materials on the substantive legal issues. As such, there is some speculation here about the course that the law will take in this area. Because of its recency, the difficult course of this type of litigation is made more apparent. However, AIDS litigation has proliferated enormously over the last several years in the United States. A similar Canadian "legal epidemic" is predicted by T. Ducharme, "Preparing for a Legal Epidemic: An AIDS Primer for Lawyers and Policy Makers" 26 Alta L. Rev. 471. 


\section{BACKGROUND OF THE HIV-INFECTED PRISONER CASE}

In late 1989, a well-known prison activist who is the spokesperson for the Prisoners' Rights Group (PRG) approached a Vancouver lawyer who worked in the area of disability rights with the plight of Mr. S., a man incarcerated in a federal penitentiary. Mr. S. had tested positive for the HIV virus and had been in segregation for nearly two years as a result of the test results. In August 1991, Mr. S. was released from the institution after serving his entire sentence under discriminatory and cruel conditions. I agreed to work on the case.

The PRG is a loosely organized group of individuals who advocate on behalf of prisoners. There are no criteria for membership and no dues are required. The group has no by-laws and is not registered as a charity, society or corporation under provincial or federal law. Its major function is to advance the argument that human rights are trampled upon in the prison system and that the system has no chance of producing rehabilitation for its prisoners. The underlying premise of the PRG is that prisons ought to be abolished. 5

Mr. S. entered the penitentiary in August 1987. Except for a short period in October 1989 , he was segregated from other prisoners when he first learned of his seropositivity. Mr. S. voluntarily asked the prison doctor to test him for AIDS shortly after he entered the institution. He says that the prison doctor assured him that the results would be confidential, but the news of the diagnosis quickly spread through the prison. Mr. S. reports that he has never threatened to infect others with the disease and that he had no fears about his own safety living in the general population.

As soon as the test result became known, Mr. S. as moved out of the living units where the general population resides. Initially he was kept in the prison hospital, but after several months, Mr. S was moved into the Dissociation and Segregation (D\&S) wing pursuant to a Commissioner's Directive which stipulates that HIV prisoners are not to reside in hospital unless they require medical treatment. ${ }^{6}$ He was not sick and needed no medical care. For the remainder of his stay at the institution, he was never returned to the general population but was housed in the Reception area.

Generally, prisoners reside in Reception when they first enter the institution. The Reception area has more security restrictions and less privacy than the Living Units. For example, lights remain on all night in Reception but are turned off in the living units, and cell entrance and exit are controlled centrally in Reception whereas prisoners have their own keys on the Living Units. The D\&S Unit has even more severe security restrictions, less privacy and fewer amenities than either the Living Units or Reception.

After his diagnosis, Mr. S was not permitted to eat in the dining room with other prisoners, and his meals were brought to his cell where he was required to eat alone one

5. Conversations with Claire Culhane, over period of January-March 1990.

6. Commissioner's Directive on AIDS: Management of Inmates with Human Immunodeficiency Virus (HIV) infection (CD:821), File No:1718-1, dated 1987-06-29. 
hour before the rest of the prisoners. For some of his period in custody, his meals were served on disposable plates, with disposable utensils, on a tray that differed in colour and shape from other prisoners', and at various times he was denied the right to attend any social functions or school classes. For some of this period, he was required to scrub the shower in D\&S with bleach each time he used it. The job he held at the time of the diagnosis was taken away from him, and he was not permitted to work until July 1989 when he was given a job as a cleaner in D\&S. He received no remuneration for the time when he was not working. After losing his first prison job, he was severely restricted in the kinds of jobs open to him.

In August 1989, Mr. S. applied for a Temporary Absence to attend an AIDS support group in the local community. He had hoped that the support group would alleviate his feelings of isolation. The terms under which he was permitted to attend were that he would be handcuffed, shackled and that a guard would be present throughout the meeting. When Mr. S. asked the support group if this were acceptable, they replied that it was not agreeable for reasons of confidentiality. Mr. S. did not attend the group.

For several months during his sentence, Mr. S. attended a program at a regional psychiatric centre where he lived in the general population with no problems. $\mathrm{He}$ considered this program an opportunity to confront his own psychological problems in a private doctor-patient relationship and spoke openly about himself while in therapy. The records of this therapy are retained by the Correctional Services of Canada (CSC), and the contents have been raised to Mr. S.'s detriment in parole hearings.

There was widespread ignorance and fear about HIV infection at the institution and any effort toward education about AIDS or HIV infection was woefully inadequate. The only direct attempt at prison education about HIV infection was a 10-15 minute video which was shown at the end of two hours of movies on prison which were shown to all newcomers. Most of the prisoners were tired and disinterested by the time the AIDS video was shown. Some time later, a community AIDS support worker left some pamphlets with the prison authorities when it was rumoured that Mr. S. was to be returned to the general population. The guards shoved these under the cell doors. Mr. S. reports that many of the prisoners shoved these back into the corridor and the guards kicked the books saying that they were mandatory reading.

Before counsel was retained, Mr. S. filed a human rights complaint with the Canadian Human Rights Commission. Six months after the complaint was received, the local office informed us that the Commission had not yet begun to work on the file. Given the Commission's back-log, it was anticipated that a hearing would be convened in about eighteen months from the receipt of the complaint. ${ }^{7}$

Despite the backlog in convening hearings, the Commission was willing to attempt negotiations with the CSC regarding removing Mr. S. from segregation. Given the limitations of resources, it was anticipated that such negotiations could occur approximately nine months from the receipt of the complaint. From telephone conversation between Lesley Stalker and Ram Singh, Canadian Human Rights Commission, Edmonton Office, May 14, 1990. 
Just a few days before Mr. S.'s release date, a lawsuit was initiated in the Federal Court of Canada. In the Statement of Claim, Mr. S. described the facts of his incarceration and sought relief from the court in the form of monetary compensation for damages, an order for an educational program to be implemented and an order that $\mathrm{Mr}$. S. be re-integrated into the general population. As well, Mr. S. sought declarations that his treatment violated sections $7,9,12$ and 15 of the Charter. ${ }^{8}$

As soon as the Statement of Claim was filed, the media showed great interest in the case. In covering the story, reporters disclosed Mr. S.'s offence which was a sexual assault of a minor. As a result of the adverse and inaccurate publicity, Mr. S. started to fear for his own safety within the institution while serving the few remaining days of his sentence.

\section{THE ROLE OF COUNSEL IN PUBLIC INTEREST LITIGATION: SPECIAL CONSIDERATIONS}

\section{A. GENERALLY}

The basic consideration in a public interest case is the question: what is the objective in examining a particular problem? In the usual case defined as a legal problem, the objective must be determined by the client's instructions and the goal is to win in the specific dispute. Indeed, the lawyer who proceeds in any other fashion will breach a major tenet of legal ethics. In the field of public interest advocacy, the objective is almost certainly to achieve a change in an existing situation but the optimal change may not be obvious at the outset to either advocate or client, because the task involves articulating the group interest and determining how a specific problem fits within the interest.

Besides litigation, a number of other avenues are almost always available in public interest matters. ${ }^{9}$ In the HIV prison case, a remedy was available from the Canadian Human Rights Commission. Negotiations with the authorities at Mr. S.'s institution regarding his situation may have achieved the result he wished. Similarly, negotiations with the Correctional Services Canada (CSC) might have produced a more general change

8. Section 7: Everyone has the right to life, liberty and security of the person and the right not to be deprived thereof except in accordance with the principles of fundamental justice.

Section 9: Everyone has the right not to be arbitrarily detained or imprisoned.

Section 12: Everyone has the right not to be subjected to any cruel and unusual treatment or punishment.

Section 15: Every individual is equal before and under the law and has the right to the equal protection and equal benefit of the law without discrimination and, in particular, without discrimination based on race. national or ethnic origin, colour, religion. sex or mental or physical disability.

9. An evaluation of the litigation option depends, to some extent, on the general tendencies of the courts at the time. The likelihood that law reform will be successful depends on how receptive govemment is. For example, in an era where the Supreme Court of Canada is moving toward more conservative decisions and provincial governments in some provinces would seem sympathetic to a variety of public interest issues, it may be advisable to seck change from government rather than the courts. For a discussion of the conservative direction of the recent decisions in the Supreme Court of Canada, see D. Beatty, "A Conservative's Court: the Politicization of Law" (199I) 16 U.T.L.J. 
in the policy regarding the treatment of HIV positive prisoners and could have ended with the development and implementation of an effective educational program. Strategies of law reform may have involved a direct appeal to the Solicitor General to interpret or change the legislation in a favourable way. As well, the media might have been used to expose the situation of HIV infected prisoners. The decision to take this matter to court was made after pursuing some of these alternatives, and rejecting others in view of the varying interests.

\section{B. FUNDING ARRANGEMENTS FOR THE LITIGATION}

The spokesperson for the PRG received funding from the Court Challenges Program ${ }^{10}$ on behalf of the group to investigate the legal problem of Mr. S. Neither the PRG nor Mr. S. had the financial resources to retain counsel in order to obtain a legal opinion on this matter. Mr. S.'s problem did not qualify him for counsel to be appointed by the legal aid organization in the jurisdiction.

The Court Challenges Program had a set of rules and procedures that affected the conduct of the cases that were funded by the program. Firstly, the funding was available for litigation only. Presumably, any other legal strategy developed to address a problem would not be funded. As well, only the portions of the case that dealt with equality issues would be funded. When other issues were raised, whether Charter arguments or not, the funding would be "discounted" by the proportion of other issues contained in the case." There were other rules of the Court Challenges Program that dramatically affected litigation although these may not be directly relevant to this case. For example, the Program as applicable only to federal law. The interpretation of the rule has been that there must be a federal defendant. Many of the most important concerns of equality to disadvantaged groups arise in matters of provincial jurisdiction, for example, health and education. Equality cases in these areas would not be eligible for funding. ${ }^{12}$

\section{DIFFERENT PARTIES IN THE LITIGATION AND DIFFERENT INTERESTS}

In private litigation, the plaintiff, the client, and the person who pays the lawyer's fees are almost always the same party. ${ }^{13}$ In public interest litigation, the "plaintiff" is often

10. The Court Challenges Program was a federally funding program to fund litigation in the areas of equality rights and language rights. In February 1992, at the time of the writing of this paper, the federal budget cancelled the Court Challenges program. Exactly what will happen to ongoing litigation was unknown at the time this paper was submitted.

11. In the case of the Canadian Council of Churches and Her Majesty the Queen and the Minister of Employment and Immigration which has been funded at the trial level and funded for an appeal of a standing question to both the Federal Court of Appeal and for leave to appeal to the Supreme Court of Canada, the budgets submitted have been reduced to $85 \%$ of the amount submitted on the basis that $15 \%$ of the case concerns matters other than equality.

12. There is a clear conflict where the federal government establishes a litigation fund to fund only matters federal. At any time (and for any reason) the government may and did cancel the program. There are situations in the resolution of private disputes where the roles described here are not merged. For example, where there is a committee or guardian ad litem who is giving instructions on behalf of the person who is the subject of a lawsuit. Similarly, there is a more complex arrangement when a party in a lawsuit is a corporation. 
distinct from the "client" who may be a public interest group. The client may be distinct from the "funder," the party paying for the services of counsel. ${ }^{14}$ Most often, a public interest lawsuit is brought by an individual who is considered from the outset to be representative and a public interest group may be a co-plaintiff. ${ }^{15}$ Less frequently, a public interest group is the sole plaintiff in an action. ${ }^{16}$ As well as the plaintiff, the client, and the funder, there is the "public interest" to consider. What is the public interest and who decides what it is? Often the result in a public interest case will have very far-reaching consequences. How far do the obligations of the lawyer extend in protecting those possibilities?

It was apparent from the outset of the HIV-infected prisoner matter that the different actors had different interests, at least in emphasis. Mr. S. wanted to be re-integrated into the general population and wanted monetary compensation for the damages he suffered. The PRG, with a group perspective, was interested in advancing the rights of prisoners and altering prison conditions generally, as well as resolving the difficulties faced by Mr. S. As part of its strategy, PRG wishes to educate the public generally and to draw attention to the restrictions of liberty faced by prisoners. The PRG's interest in this particular matter was to expose the harsh and inhuman treatment of prisoners with HIV infection and to see an effective AIDS education program implemented in the prisons. The Court Challenges Program was interested in this case as far as it contributed to equality jurisprudence in Canada. It is fair to assume that the people administering the program were predisposed to cases that would advance the rights of various minority groups. However, the program criteria gave the administrators sufficient discretion that their sense of what advances minority interests became important.

How much of the public interest should we take into account in the Prisons and AIDS work? In developing a strategy, we planned to consult with disability groups, AIDS support groups, and advocacy groups representing high risk populations. What of the views of groups who were advocates for "victims of crime?" In the broadest definition of public interest, these groups would certainly have views on the treatment of HIV infected prisoners, but they were not consulted in this case. The decision to exclude such

14. For the purpose of this paper, the plaintiff is described as being the subject of the lawsuit, the party with whom there is a lis with the defendant as seen by the Court. The client is the public interest group or other individual who is primarily responsible for the carriage of the case and giving instructions on the general issue in question. The funder is the individual or group that is paying for the litigation.

15. For example, in Brown v. British Columbia (Minister of Health) (1990), 66 D.L.R. (4th) 444 (B.C.S.C.), a case that alleged that the failure of the medical insurance plan to pay for experimental AIDS drugs contravened section 15 of the Charter, the named plaintiffs consisted of several individuals as well as the Persons with AIDS (PWA) advocacy group. One of the unfortunate considerations in AIDS litigation is the possibility that an individual plaintiff will die of the disease before the matter is heard in court.

16. The B.C. Civil Liberties Association was the sole plaintiff in the review of a regulation which did not permit medical insurance to cover abortions in B.C. Civil Liberties Association v. British Columbia (A.G.) (1988), 49 D.L.R. (4th), 493 (B.C.S.C.). 
a consideration illustrates the extent to which a public interest lawyer may shape the outcome of a problem. ${ }^{17}$

What happens when there is a disparity of interest or a conflict among the actors? For example, counsel was of the opinion that we should include a claim that the treatment of HIV infected prisoners was a form of cruel and unusual punishment although the law prescribed a very high standard for a breach of section $12 .{ }^{18}$ We felt there was an argument that the transfer of HIV infected persons to any specialized facility without any appropriate process violates sections 7, 9 and 12 of the Charter, in addition to section $15 .^{19}$ Would that mean that only 25 percent of the case would be funded because of the funding rules? Should counsel develop an argument that the other breaches were based on a section 15 violation in order to preserve the funding possibility. If so, this would be a dramatic demonstration of the way in which jurisprudence is shaped by the rules of funding, rather than the facts of a particular case or the group interest supporting the litigation.

While counsel recognized that the courts would be reluctant to order an education program because of the general reluctance to issue injunctive relief against government, ${ }^{20}$ a remedy for Mr. S. was available through negotiations with the Canadian Human Rights Commission which had a policy on prisons and AIDS. Remedial programs to prevent the recurrence of discriminatory attitudes are specifically provided for in the human rights legislation. ${ }^{21}$ We would argue, using the same reasoning as the decision in Robichaud ${ }^{22}$

17. One of the great difficulties of public interest advocacy is the absence of standards to confirm the representative character of the groups we look to as articulators of the interests we seek to have represented. Who we decide are the legitimate stakeholders in an issue and who ought to be regarded as representative of the stakeholder is a central dilemma that is answered in the context of our own politics.

18. R. v. Smirh (1987), 5 W.W.R. 1 .

19. For a thorough review of the due process requirements when transferring HIV infected persons to specialized units in the United States see L.S. Branham, "Out of Sight, Out of Danger?: Procedural Due Process and the Segregation of HIV Positive Inmates" (1990) 17 Hastings Constitutional Law Quarterly 293.

For an excellent analysis of the court's dilemma between deterrence and intrusiveness in the types of injunctive relief, see P.H. Shuck, Suing Government, Citizen Remedies for Official Wrongs (Yale University Press, 1993). As well, see R. Sharpe, "Injunction and the Charter" (1984) 22 Osgoode Hall L.J. 473.

2t. The Canadian Human Righrs Act, c. H-6, Section 53(2)(a) empowers a tribunal to order the person who has been found engaged in discriminatory practices to

...cease the discriminatory practice and, in order to prevent the same or a similar practice from occurring in the future, take measures,

(i) including the adoption of a special program, plan or arrangement...

22. In Robichaud and the Canadian Human Rights Commission v. Her Majesty the Queen as represented by the Treasury Board, [1987] 2 S.C.R. 84 (S.C.C.), the issue in Robichaud was whether an employer was liable for the sexual harassment of an employee under federal human rights legislation. The Court found that the goal of human rights legislation is to eliminate "anti-social" conditions and reasoned that the legislative intent was best served by placing responsibility for the discriminatory acts of an employee on those who are ultimately in control and can take the necessary steps to remedy the situation on this analysis. The Court held that the employer was liable since it was in the best position to eliminate the discriminatory environment. In applying the principle to the current case, the prison authorities have a statutory responsibility or prisoners in their custody, and are in a 
that the responsibility to provide an effective educational program to eliminate the discrimination was with the CSC.

Since the human rights process was likely to be faster than the litigation, and presented a more straightforward approach to the relief sought by $\mathrm{Mr}$. S., the human rights avenue seemed a more desirable option than Charter litigation for the plaintiff. While this may have been the best choice for the plaintiff, it would mean a more private settlement that would not serve the group interest of the PRG as well as would litigation.

What of the media? The media was fascinated with this case and requests were made from print journalists as well as radio and television reporters. From the group perspective, increased publicity was beneficial. For the individual plaintiff, Mr. S., who, as a prisoner had already placed himself in some jeopardy by initiating the litigation, increased media coverage of his legal problem placed him in further jeopardy.

\section{THE REPRESENTATIVE PLAINTIFF}

Public interest litigation usually means putting forth a representative plaintiff in order to fulfil the rules of standing and to present a compelling case to the court. Although there was some hope that the courts would be more expansive in granting standing to public interest groups advancing Charter challenges, the early indication of the Supreme Court is that the rules will remain the same.

Once a decision is made to litigate, it is the facts of the particular plaintiff's situation that will be the basis of the judicial pronouncement that ensues with respect to the group interest. $^{23}$ How representative is the plaintiff? Finding the answer to this critical question forms much of the preparatory consultative work in public interest litigation.

At the outset of the HIV prison research, we had no reason to believe that Mr. S. was typical since he was asymptomatic, receiving good medical care, and in an institution that

unique position of power. Given the reality of prison life and the power imbalance between prisoners and staff, the CSC and the institutional authorities should be made responsible for educating prison staff and prisoners so that ignorance about AIDS does not result in threats fears and drastic action against prisoners who are infected with the HIV virus.

"Test case" has come to be used as a term of art rather than science. Here it is used to refer to a case that revolves around some novel element in law or social policy. One cannot, of course, lose sight of the fact that important issues to the public interest may be raised in more traditional lawsuits where the purpose of the case is restricted to how matters directly affect the individual plainitiff: however, because the case has involved representative issues, the resulting law is felt much more widely. For example, criminal cases where Charter issues are raised have as their purpose, the interests of the defendant. However, as the issues may be representative, the resulting law is felt more widely. Even in these cases, courts are allowing intervenors to present altemative perspectives. See for example, R. v. Sullivan (1991), 3 C.R. 4th 277 (S.C.C.) where two midwives were prosecuted under sections of the Criminal Code of Canada. Because the issues would involve matters of particular concem to women, both L.E.A.F. and R.E.A.L. Women were allowed to be intervenors. 
did not have a wing for protective custody. ${ }^{24}$ Critical to what Mr. S. wanted, that is to be released to the general population, was his firm belief that he would be in no serious danger by remaining in the general population.

The task in assessing Mr. S. as a representative plaintiff included investigating the extent of the problem or the numbers of HIV infected prisoners in Canada, the ways in which they are treated, and determining that individuals and groups with various perspectives on the question believed was the best outcome. We obtained wildly discrepant views of the extent of the problem. On the "minimal problem" side were the B.C. Human Rights Council, the Canadian Human Rights Commission ${ }^{25}$ and the Correctional Services Canada (CSC). ${ }^{26}$ Not surprisingly, on the "significant and pressing problem" side were activists in the gay and prison rights communities.

We questioned the accuracy of the CSC figures because they relied on self reporting of HIV infected prisoners. ${ }^{27}$ One can safely assume that prisoners are unlikely to report their infection because of the mistreatment by both staff and other prisoners that is likely to follow. Elimination of the discriminatory and harsh treatment of infected prisoners would undoubtedly result in more disclosure by known carriers and requests for voluntary testing. Those who test positive could then receive the medical attention and treatment that would delay the onset of the disease. ${ }^{28}$

As we obtained more information from those with a "prisoners' rights" perspective, we became increasingly aware of the need for the views of advocacy groups where HIV infection is of concern for the high risk sub-groups of the prison population. More simply, we thought that those closer to the issue as a disease that has long been viewed as the "gay plague" may have important and different input. There is, for example, strong

24.

Protective custody is a wing for those who would be in physical danger were they placed in the general population. Usually these are prisoners who are informers or have been convicted of sexual offences.

25.

The B.C. Human Rights Council reported that it had received no complaints from prisoners alleging that they had been discriminated against on the basis of the HIV infection. The Canadian Human Rights Commission told us that it had received no such complaint as of February 1990, despite he fact that such a complaint was filed in November 1989, and the CHRC had acknowledged receipt of it.

26. The Correctional Services Canada (CSC) informed us that as of February 2, 1990, there were twentyfour prisoners in federal penitentiaries who had been diagnosed as HIV positive and there were no prisoners with AIDS in the system as of that date. According to this information, twenty-two of the 24 were in the general population, one in the Health Centre and one in disciplinary dissociation. The low figure clearly reflects the CSC policy of no mandalory testing in the penitentiaries. While the question of mandatory testing of prisoners for the AIDS virus is a live question in the United States there is no serious consideration of this in Canada. We found no official SC position that it would support mandatory testing, there may well be support for it among on-line workers, in particular, the guards. Similarly, although there is certainly no support for mandatory testing among prisoners' activist groups, individual prisoners may have different views. testing of HIV-infected persons as contemplated in the Ontario public health legislation, see W. Flanagan, "Equality Rights for People with AIDS: Mandatory Reporting of HIV Infection and Contact Tracing" (1989) McGill L.J. at 530. See also, J. Hamblin and M. Somerville, "Surveillance and Reporting of HIV Infection and AIDS in Canada: Ethics and Law" (1991) 16 U.T.L.J. 224. 
suspicion among gay activists that testing for the AIDS virus is done without consent while doing other blood tests for which proper consent has been obtained if a prisoner is a member of a group known to be at high risk for the virus. ${ }^{29}$

According to the Persons with Aids Coalition (PWA) in Vancouver, many of their members have served prison time and the common experience is that every prisoner who is known to be HIV positive has been segregated, assaulted or otherwise mistreated by staff or prisoners. ${ }^{30}$ In contrast to the PRG and our representative plaintiff, Mr. S., a spokesperson of PWA saw any policy of integration of HIV positive prisoners as potentially explosive, and simply not in the interest of its constituency. He recommended separate protective-custody-like facilities for known HIV positive prisoners. ${ }^{31}$

The unique consideration in public interest litigation is the possibility of an overbroad ruling by the Court or a very narrow view confined strictly to the facts of the case. If the Court's view of a pressing public issue is shaped by the facts of the specific case in a way that results in an overbroad ruling, the remedy suitable for Mr. S. would be applied in other situations in which it was not suitable. The converse problem is the possibility that the Court will use the narrowest interpretation of the facts of Mr.'s case to avoid a more general comment on the rights of prisoners with AIDS. Thus, from the viewpoint of the PRG and the Court Challenges Program, a case that was to be of general import could turn into a case that was of value only to Mr. S.

Special consideration needs to be given to litigation strategies where the representative plaintiff suffers a significant deprivation of liberty or is otherwise especially vulnerable at the hands of the defendant, as this places the plaintiff and the ongoing litigation in a particularly precarious position. For instance, where a plaintiff is incarcerated and the defendant is able to release the individual, the defendant may choose to release the person who is the plaintiff and then argue that the lawsuit before the court is moot. From the defendant's perspective, release of the particular person may be a better choice than the risk of a court decision that will result in a more general change. ${ }^{32}$ This is especially

Conversation among the writers, Lesley Stalker, Dennis Dahl and Kevin Robb. Mr. Dahl and Mr. Robb are Vancouver lawyers who have represented many gay clients on AIDS-related issues. If the speculation about surreptitious lesting for the HIV virus is true, the CSC has not released accurate figures to us, and perhaps the extent of the problem is known only at a particular level of the bureaucracy in order to keep a "lid on the problem and to avoid panic."

30. Conversation with David Lewis, representative of the Persons with AIDS Coalition, April 2, 1990.

31. To complicate matters further, we subsequently leamed that the "separate but equal" facilities remedy was the view of only one vocal member of PWA and did not reflect the view of the group which had not yet developed a policy.

32. Prison litigation and mental health litigation are plagued by this problem. Often when there is the threat of litigation regarding the legality of a decision to transfer a prisoner, the prisoner's wishes are complied with an order to avoid a court ruling on the more general question. Similarly, when an involuntary patient begins to litigate, the patient is released. For example, in several cases that challenged the constitutionality of immigration restrictions for persons with disabilities under the Immigration Act, the Minister has exercised the discretion available to make whole families permanent residents of Canada rendering moot the challenge to the statute, according to David Baker, Executive Director of the Advocacy Resource Centre for the Handicapped. Similarly, Lemay v. Kilby (1987), December 31, 1987. Unreported; a constitutional challenge to important sections of the 
troubling when the "representative" individual is selected by a public interest group because of the potential conflict between the short-term interests of the individual and the long-term interests of the group.

In order to avoid this possibility in the Prisons and AIDS case, we intend to include additional plaintiffs, one of which will be a public interest group. ${ }^{33}$ In addition, Mr. S. will seek damages in the action. While there are obviously other reasons to include a claim for damages, the act on is preserved with the presence of this damage claim in the event of argument that Mr. S.'s release renders the matter moot.

\section{E. SHORT-TERM AND LONG-TERM CONSEQUENCES OF LITIGATION}

Since litigation is to be viewed as part of a group's larger political goals, we needed to assess how the remedy sought by Mr. S. fit into the political agenda of the group, the PRG. There needed to be some consideration of whether attempting to improve prison conditions in any way was consistent with the abolitionist in such a way that would make them pleasant places to die. ${ }^{34}$

A different strategy, more consistent with the aims of the group interest, would involve seizing the opportunity to be creative about AIDS and health care generally, in the prison system. Perhaps there should be an effort to have CSC adopt a policy that release, perhaps through the Royal Prerogative of Mercy, be facilitated for persons in the advanced stages of AIDS, because our society should not condone the continued incarceration of people who are dying and no longer represent a threat to society. The idea that people should not have to die in prisons is not unique to persons suffering from AIDS, but the AIDS issue may be the wedge that could be used to convince the author ties of this more general humane principle. ${ }^{35}$

Mental Health Act of B.C., the B.C. Supreme Court found the matter to be moot because the plaintiff had been released from the particular admission upon which the facts were based, despite the fact that he had been involuntarily committed on more than 20 occasions, and was on the day of trial, in hospital as an involuntary patient again. But see footnote 2 for the state of the law regarding public interest groups as plaintiffs.

A similar conflict exists for the Prisoners' Rights Group and its counsel in the case of an Inuit man who alleges that Inuit people suffer systemic discrimination by their incarceration in southern federal penitentiaries. The largest difficulty for Inuit prisoners is the long distances from the home community to the penitentiary. Among other more patchwork solutions to this discrimination, the Prisoners' Rights Group must consider the recommendation that federal facilities be built in the north. A recommendation to build more prisons appears to be completely at odds with the overall political position of PRG.

35. In the case of $R$. v. Downey, a man in an advanced stage of AIDS related Complex (ARC) was incarcerated at the Don Jail in Toronto pending his trial. He was beaten by guards after being accused, falsely, of spitting at and biting a guard, and was transferred to a maximum security detention centre to diffuse the panic which was spreading among the staff. The indignities he suffered at the detention centre included solitary confinement, the appearance of cigarette butts and other objects in his food. The judge held that the conditions under which Mr. Downey was held were cruel and unusual punishment in view of his medical condition and released him on bail. While the release was not based on the medical condition per se, it was the mistreatment which the person suffered because of the diagnosis that convinced the judge to release him. 
A successful piece of litigation, defined as obtaining the relief sought from the Court, may not provide the immediate "success" expected in solving the problem. Indeed, it may backfire by the way that a judicial pronouncement is interpreted. Similarly, an unsuccessful piece of litigation may not mean a failure for the objectives of the client.

Public interest groups know that the important site for implementing judicial pronouncements is not in the courtroom but within the bureaucracy. What the judge has said is usually not nearly as important as how it is interpreted by the bureaucrats. Sometimes litigation creates some confusion and results in a re-interpretation of the situation by the bureaucracy and the community that may be of benefit. ${ }^{36}$ Therefore, it is critical that any strategy, litigation-driven or otherwise, be evaluated with a good knowledge of the particular system involved in the problem. The bureaucracy and persons who manage the mental health system will operate differently than the bureaucracy and persons involved within environmental matters. Different systems may be more politically vulnerable to change so that the risk of "losing" the litigation is tempered by the increased profile of the issue because of the litigation.

In Silano, ${ }^{37}$ the B.C. Supreme Court held that welfare regulations giving lower benefit rates to persons under twenty-six years of age than those over twenty-six years of age violated the section 15 equality provisions of the Charter prohibiting discrimination on the basis of age. The B.C. government responded by lowering the welfare rates for those over twenty-six, such that both age groups received the same amount of benefits. If the objective of the welfare rights group that orchestrated the lawsuit were to raise the total amount of benefits received by the community, the lawsuit failed.

In Howard, ${ }^{38}$ the Federal Court of Appeal decided that a prisoner had the right to be represented at disciplinary hearings when accused of certain categories of offences and under certain conditions. This decision could have meant a much fairer process of disciplinary hearings within the prison system. However, the penitentiary system responded by altering the categories of offences that could be touched by the Court's ruling such that the right to representation by counsel was once again severely limited. ${ }^{39}$

In Fenton v. Forensic Psychiatric Services Commission, ${ }^{40}$ the British Columbia Supreme Court found that some of the work performed by patients at the Forensic Psychiatric Institute was covered by the minimum wage provisions. Further, the court

While the interpretation of a court's seemingly favourable decision by the bureaucracy is indeterminant, the political consequence of a court "loss" is also indeterminant. For example, in $R e$ Pirbhai (1983), 3 D.L.R. (4th) 181 (B.C.S.C.) refugee claimants were denied welfare payments by regulation. The Altorney-General successfully appealed a decision of a tribunal that found a refugee claimant to be eligible for welfare. Following the community's reaction to the decision, the regulation was amended to include refugee claimants. Silano v. British Columbia (1987), 33 C.R.R. 331 (B.C.S.C.).

How ard v. Stony Mountain Institution (1984), 45 C.R. (3d) 242 (Fed. C.A.).

For an excellent analysis of Howard and the history of the right to counsel within the Canadian prison system, see M. Jackson. "The Right to Counsel in Prison Disciplinary Hearings" (1986) 20 U.B.C. Law Rev. at 222.

Fenton v. Forensic Psychiarric Services Commission (1989), 29 C.C.E.L. 168 (B.C.S.C.). 
struck down a regulation that exempted an employer from paying the minimum wage where the program was for the purposes of rehabilitation because it violated section 15 of the Charter. However, the Court of Appeal decided that the activities did not constitute work as contemplated by the Employment Standards Act. ${ }^{41}$

For the purposes of this paper, the response of the disability community to the "success" of the Fenton decision in the Supreme Court is interesting because of its ambivalence. Clearly, there is a victory in a judicial pronouncement that what psychiatric patients do and what they make is "work" and therefore of value. At the same time, there is great concern that the funding for a whole range of sheltered workshop programs is not, and will not soon be, sufficient to permit the payment of minimum wage. The worry is that such programs may be closed down if a ruling mandated the payment of minimum wage in all sheltered workshop programs.

The cases of Silano, Howard, and Fenton (at the Supreme Court level) represent cases where, to varying degrees, the litigation was successful but the problem that drove the litigation was not immediately resolved by the successful outcome of the lawsuit. These cases may be viewed as "incomplete victories" and worthwhile because they have advanced the principles of equality or due process that they stand for, and place the client group in an advanced position generally, after the litigation.

In Silano, the Court established that the government could not pay differential benefits according to age. The value of the decision is its statement of equality with the result that the government may not divide the welfare community in such a discriminatory way. Similarly, Howard establishes a right to counsel in certain disciplinary hearings although it does not establish that the right is to paid counsel, nor does it prevent the type of reclassification that dampened the effect of that decision.

Although there was anxiety about the survival of sheltered workshops expressed by disability rights activists in the wake of the Supreme Court's decision in Fenton, such a decision may place new pressures on the Forensic Psychiatric Services Commission (FPSC). ${ }^{42}$ Prior to Fenton, the work program characterized as therapy served two purposes for the defendant. Since the FPSC has a statutory duty to provide therapy services, the work program when characterized as a program of therapy, helps to legitimate the PSC. The second benefit to the defendant was simply monetary, because the legislation authorized a situation in which an employer was relieved of paying the minimum wage to its workers and enabled it to earn more profit. To some extent, the Fenton decision in the Supreme Court removes both of those benefits from the employer. If the program is characterized as work, even if that work, like any other work, has a therapeutic benefit, it can no longer be characterized exclusively as therapy and does not

41. Fenton v. British Columbia (Forensic Psychiatric Services Commission) (1991), 82 D.L.R. (4th) 27 (B.C.C.A.). Leave to appeal to the Supreme Court of Canada has been denied.

s2. The Forensic Psychiatric Services Commission, a body governed by the Forensic Psychiarry Act, R.S.B.C. 1979, Ch. 139 assumes a number of roles in this situation. Its duties include the provision of therapy services. As well, it acts as the employer or management with respect to the activities of the work program while the patients are the employees or workers. 
serve to legitimate the function of the FPSC to the same extent. Because of its statutory duty, the authorities would presumably need to initiate a more reasonable form of therapy. As well, since the defendant can no longer benefit from the minimum wage exemption, management could alter the conditions of the workplace to make it more competitive so that workers could be paid the minimum wage. Because those alterations would create a more realistic workplace, the program would be a more serious effort to integrate people with mental disabilities into the workforce.

How far-reaching and how long-term need the considerations be? The important point is how any lawsuit leaves the group positioned with respect to the changes being sought, rather than whether the particular lawsuit is a win or a loss. ${ }^{43}$ For example, the disability community has had many discussions of the appropriate litigation strategy for cases involving differential wage rates for persons in sheltered workshop settings. There has been a sharp difference of opinion within the community as to whether the Court should be presented with an argument (albeit in the alternative), that persons in a particular work program need not be protected by the statutory minimum wage that protects almost every other worker, but that some minimum wage protection is necessary. This lesser protection currently exists under the Employment Standard Act of British Columbia for such groups as farmworkers and domestic workers, groups that will probably try to claim a section 15 violation precisely because of the lesser protection. If a lawyer needs to consider the interests of farmworkers and domestic workers in a case that is about the rights of the mentally disabled, the lawyering job is clearly a far broader activity than claiming damages for a client involved in a motor vehicle accident.

\section{CONCLUSIONS}

The objective of public interest advocacy is to articulate and advance a group interest. However, the more common understanding of law and the rules of litigation are oriented around dispute resolution and simply do not provide a very good fit for the objectives of the public interest advocate.

The traditional structure of the lawyer-client relationship is less appropriate in a public interest action. The orthodox canons of ethics which are the touchstone of our legal practice, do not provide the guidance we need as public interest lawyers. The ethical dilemmas are different, as they are for practitioners in class actions. ${ }^{44}$ With a shift in

For a discussion of the success of "repeat performers," who participate in litigation to improve an overall position, not to win a particular dispute, see M. Galanter. "Why the 'Haves Come Out Ahead: Speculations on the Limits of Legal Change." (1974) 9 Law and Society Review 95. Since Professor Galanter concludes that there is a structural unfairness to litigation between an organized entity that picks and chooses when to litigate and the ordinary individual, he suggests that both alternate forums of dispute resolution and alternate delivery of legal services are necessary. Sce M. Galanter "The Duty Not to Deliver Legal Services" (1976) 30 University of Miami Law Review 929.

4. For a discussion of how the ethics of legal practice are not appropriate to the practitioner who deals with class action suits, for example, failing to provide ethical guidelines regarding the necessity of including all requisite plaintiffs in a class, see B.J. Waid. "Ethical Problems of the Class Action Practitioner: Continued Neglect by the Drafters of the Proposed Model Rules of Professional Conduct" (1981) 27 Loyola L. Rev. 1047. 
priorities, the sharp division between the client whose job it is to give the instructions and the lawyer whose job it is to run the case may need a re-definition in public interest matters. ${ }^{45}$

The divergent interests may result in a conflict between the "plaintiff" (if a representative plaintiff is chosen) and the client. If the instructions are being given by a group, does the lawyer have an obligation to define the interests of the individual plaintiff and how should she define these interests? ${ }^{46}$ A reasonable rule of practice in these circumstances would be that representative plaintiffs should be represented by separate counsel at least to address the question of remedy. While the interests of the "common good" should be carefully explained to the representative plaintiff throughout the process. the individual's special interest deserves separate representation and advocacy. In litigation where the issues are defined before the court as more broad-based than the facts of the individual case, the individual plaintiff effectively becomes an intervenor when that person remains separately represented.

A public interest lawyer may have a special obligation to prevent the client from making strategic choices injurious to the public interest. Since the criteria for choices injurious to the public interest are far from clear in most cases, any duty that the lawyer has to the public interest may be analogous to the more traditional duty of the lawyer as an officer of the Court. Unlike their duties to other persons in legal work, for example clients or other lawyers, Officers of the Court are bound to uphold a broader interest. The broader interest stems from a fundamental value that the Court can only operate as an arbiter of justice when fully informed and accessible. A lawyer as Officer of the Court has a special duty to protect the underlying values that enable the Court to function. As one's duty to the Court may supercede one's other ethical duties as a lawyer, the duty to solve the public interest problem may supercede other traditional duties of the lawyer. The danger in this characterization of a lawyer's duty is the conclusion that a public interest lawyer is obligated to argue both or all sides of a question to the Court. If that is so, the adversarial model which formulates the basis of litigation disintegrates entirely and an alternate forum is imperative to resolve public interest matters.

The particular role of the lawyer is to import the skills of a lawyer's training to give input to a problem. The lawyer's expertise in doing legal research, conducting mediation sessions, or providing advocacy skill is but one aspect of the expertise required to solve the problem. In the AIDS and Prisons case, some of the people were "experts" in understanding the attitude of homophobia and others were experts in the prison system. The "expertise" may be derived from direct experience or through formal learning. As a cooperative model, the power, responsibility, and actual work on the problem is more equally shared by all of the actors that are involved in solving the problem.

For example, Paul Emond describes the specific public interest dealt with by the environmental lawyer, as part of a problem that everyone, including the environmental lawyer, is responsible for solving. In P. Emond, The Greening of Environmental Law (DRAFT PAPER).

46.

The practice of LEAF is that the plainitiff in an action instructs counsel but LEAF supports the case and monitors the litigation. If the organization disagrees with the general direction of the litigation, it will withdraw its support of the case. 
There needs to be proper funding for advocacy in public interest matters and funding schemes that do not distort the process. If the exercise is to explore the legal parameters of a social problem, it does not make sense at the outset to set out that the problem is to be solved with a specific legal argument in a particular venue. The funding base needs to take into account all of the alternate strategies. In the present example, the problem was to change the manner in which the CSC dealt with HIV infected prisoners. To cast that task in a form such that only a section 15 argument can be paid for, is to distort the task completely out of shape.

Finally, legal training must take into account that there is a fundamentally different job to be done by public interest lawyers. This may mean a radical change in legal education, both in admissions policies and curriculum. If there is a fundamentally different job to be done by public interest lawyers, the skills, perspectives and knowledge necessary to do that job will be different. 